\title{
POLITIK HUKUM \\ KEBEBASAN BERAGAMA DAN BERKEPERCAYAAN \\ DI INDONESIA
}

\author{
Oleh: Budiyono \\ Fakultas Hukum Universitas Lampung \\ Email : budifathia@yahoo.co.id
}

\begin{abstract}
Abstrak
Indonesia adalah negara berdasarkan Ketuhanan Yang Maha Esa yang mengandung prinsip bahwa bangsa Indonesia adalah bangsa yang beragama walaupun bukan negara agama. Agama dapat hidup dan berkembang dengan jaminan dan perlindungan negara, sedangkan para pemeluk agama berhak melaksanakan dan mengembangkan agama sesuai dengan kepercayaannya. Prinsip kebebasan beragama dan berkepercayaan itu merupakan pengakuan dan jaminan serta perlindungan bahwa setiap orang bebas dan merdeka menganut agama dan kepercayaan yang diyakininya. Tujuan penelitian ini adalah bagaimana politik hukum negara Indonesia dalam menjamin kebebasan beragama dan berkerpercayaan berdasarkan UUD 1945.
\end{abstract}

Kata kunci : politik hukum, kebebasan beragama

\begin{abstract}
Indonesia is state pursuant to believing in god principle that Indonesian nation which believe in although non religion state. religion life and expand with guarantee and protection of state, while all of people entitled to execute and develop religion as according to its trust. Freedom of religion principle and that trust represent guarantee and confession and also protection that free each and everyone and independence to embrace believed trust and religion. research purpose is how Indonesia legal policy to guarantee and protection be based on the constitution 1945
\end{abstract}

Key word : legal policy, freedoom of religion

\section{A. Pendahuluan}

Salah satu ciri dari negara hukum adalah adanya jaminan perlindungan terhadap hak asasi manusia oleh negara kepada warga negaranya. Kebebasan beragama dan berkepercayaan merupakan salah satu bagian penting dari hak asasi manusia. Jaminan kebebasan beragama dan berkepercayaan warga negara dijamin secara konstitusional dalam Pasal 29 UUD 1945. Setelah perubahan UUD 1945, kebebasan memeluk agama dan kepercayaannya dimuat dalam bab tentang hak asasi manusia (HAM) yang dijamin dan dilindungi oleh negara yaitu Bab XA Pasal 28E ayat 1 dan 2 serta Pasal 28I.

Pasal 28E ayat (1) :

" setiap orang bebas memeluk agama dan beribadat menurut agamanya, memilih pendidikan dan pengajaran, memilih pekerjaan, memilih kewarganegaraan, memilih tempat tinggal di wilayah negara dan meninggalkanya, serta berhak kembali."

Pasal 28E ayat (2) "setiap orang berhak atas kebebasan meyakini kepercayaan, menyatakan pikiran dan sikap, sesuai dengan hati nuraninya".

Hak beragama juga diakui sebagai hak yang tidak dapat dikurangi dalam keadaan apapun berdasarkan Pasal 28I Ayat (1) UUD 1945. Konsekuensi dari adanya jaminan tersebut, setiap orang wajib menghormati kebebasan beragama orang lain (Pasal $28 \mathrm{~J}$ ayat (1) UUD 1945). Sebagai hak konstitusional dan hak asasi, negara bertanggungjawab atau berkewajiban untuk mempromosikan (to promote), melindungi (to protect), memenuhi (to fulfill), kebebasan beragama dan berkepercayaan (Pasal 28 I ayat (4) UUD 1945). Pasal 22 Ayat (1) Undang-Undang Hak Asasi Manusia No. 39 Tahun 1999 menyatakan bahwa setiap orang bebas memeluk agamanya 
dan beribadat sesuai dengan kepercayaanya yang diyakini. Berdasarkan pasal-pasal tersebut, ada dua aspek dalam kebebasan beragama dan berkepercayaan yaitu :

pertama : kebebasan setiap warga negara untuk memilih agama atau menentukan agama dan kepercayaan yang dipeluk, serta kebebasan melaksanakan ibadah menurut agama dan keyakinan masing-masing.

Kedua : kebebasan dan kemerdekaan menyebarkan agama, menjalankan misi atau berdakwah dengan syarat semua kegiatan penyebaran agama itu tidak menggunakan caracara kekerasan maupun paksaan secara langsung maupun tidak langsung.

Setiap warga negara memiliki hak untuk menganut dan melaksanakan agama dan kepercayaanya sesuai dengan keyakinan masingmasing, namun dalam konteks nasional, negara juga wajib mengatur agar dalam kehidupan beragama tidak terjadi benturan antara penganut agama yang satu dengan penganut agama lainya. Pasal 29 UUD 1945 secara tegas memberikan tugas kepada negara untuk menjamin kebebasan beragama dan beribadah bagi para pemeluknya. Peran negara diperlukan untuk menciptakan dan memelihara suasana kebebasan beragama dan kerukunan umat beragama guna mewujudkan masyarakat Indonesia yang aman, damai, sejahtera dan bersatu.

Pelaksanaan prinsip kebebasan beragama dan berkepercayaan tersebut, mengalami pasang surut. Timbulnya kebijakan negara yang menentukan aturan hukum mengenai apa yang seharusnya berlaku untuk mengatur kehidupan beragama dan berkepercayaan di Indonesia menjadi hal yang perlu dikaji, untuk menentukan kebijakan yang ideal yang sesuai dengan citacita berbangsa. Berdasarkan hal tersebut, maka tulisan ini disusun dalam upaya memahami politik hukum mengenai kebebasan beragama dan berkepercayaan di Indonesia.

\section{B. Pembahasan}

\section{Jaminan Kebebasan Beragama dan Berkepercayaan dalam UUd 1945}

UUD 1945 sebagai sebuah konstitusi ditetapkan oleh Panitia Persiapan Kemerdekaan Indonesia (PPKI). UUD 1945 dirancang oleh Badan Penyelidik Usahausaha Persiapan Kemerdekaan (BPUPK) pada tanggal 29 Mei 1945 sampai dengan tanggal 16 Juli 1945 (Sri Soemantri, 1987 : 3). Dalam Sidang Pertama BPUPKI tangal
29 Mei yang membahas dasar negara terjadi perdebatan antara Golongan Nasionalis atau Kebangsaan dengan Golongan Islam (Taufik Abdullah, 1998 : xxxiii). Muhammd Yamin mengajukan saran dasar negara terdiri dari: Peri Kebangsaan, Peri Kemanusian, Peri Ketuhanan, Peri Kerakyatan dan Kesejahteraan Rakyat (Ahmad Sukarja, 1995 : 7). Soepomo dalam pidatonya tanggal 31 Mei 1945 menyampaikan pilihan tiga teori negara, yang disebutnya sebagai teori perseorangan, teori golongan dan teori integralistik yang sesuai dengan pemikiran ketimuran. Oleh karena pemimpin bersatu jiwa dengan rakyat, Soepomo memandang tidak perlu diadakan jaminan hak-hak warga negara secara eksplisit dalam UUD 1945 (Taufik Abdullah, 1998 : xxxiii).

Sedangkan Soekarno dalam pidatonya pada tanggal 1 Juni 1945 berusaha mengkompromikan kedua pendapat golongan di atas. Soekarno menyarankan lima prinsip dasar negara yang disebut sebagai "Pancasila" yang terdiri dari Kebangsaan, Internasionalisme, Permusyawaratan, Perwakilan, Kesejahteraan dan Ketuhanan. Selain lima sila tersebut Soekarno menawarkan pilihan lain yang dinamakan" Trisila" yang terdiri dari socio-nasionalisme, socio-democratie dan Ketuhanan yang menghormati satu sama lain. Sekiranya dua dua dasar ini belum dapat diterima Soekarno menawarkan pilihan ketiga yang disebut “ Ekasila" yaitu gotong royong (Taufik Abdullah, 1998 : xxxiii).

Hatta menerima usul Soekarno tentang dasar Pancasila, tetapi ia berbeda mengenai penempatan sila Ketuhanan (isi pidato Soekarno menempatkan sila Ketuhanan sebagai sila kelima). Ia menempatkan sila Ketuhanan sebagai sila pertama. Ia berpendapat bahwa sila Ketuhanan memberi dasar yang kokoh bagi sila yang lainya (Deliar Noer, 1990 : 222-223). Dalam sejarahnya sila Ketuhanan atas usul wakil-wakil Islam berubah menjadi Ketuhanan Yang Maha Esa (Muh Yamin, 1960 : 437). Sedangkan pandangan Agus Salim tentang Pancasila, juga ditekankan pada sila pertama Ketuhanan Yang Maha Esa.

Pada saat penyusunan batang tubuh, terutama, Pasal 29 ayat (2) yang menyangkut kebebasan beragama terjadi perdebatan di kalangan perancang undang-undang dasar. Wachid Hasjim mengusulkan, bahwa "agama negara adalah Islam, dengan menjamin 
kemerdekaan orang-orang yang beragama lain" (Muh. Yamin, 1960 : 262). Mengenai usulan tersebut, Otto Iskandardinata mengusulkan Pasal 29 supaya kalimat preambule dimuat dalam Undang-Undang Dasar sebagai ayat (1) dan " negara menjamin kemerdekaan ...dan seterusnya menjadi ayat (2)."

Sedangkan Wongsonegoro menyatakan bahwa " negara boleh memaksa orang Islam untuk menjalankan syariat agama, maka diusulkan supaya pasal 29 ayat (2) ditambah dengan kata-kata "dan kepercayaannya" antara kata-kata agama dan masing-masing (Muh. Yamin, 1960 : 262).

Atas usul Otto Iskandardinata dan Wongsonegoro tersebut, Soepomo sebagai Ketua Panitia Kecil tidak keberatan untuk menerimanya. Radjiman mengambil keputusan dan menyakan rumusan itu diterima dengan suara bulat, Pasal 29 UUD 1945 berbunyi:

1. Negara berdasarkan atas ke-Tuhanan Yang Maha Esa.

2. Negara menjamin kemerdekaan tiap-tiap penduduk untuk memeluk agamanya dan beribadah menurut agamanya dan kepercayaannya itu.

Demikianlah kebebasan beragama yang berhasil disepakati dan dimasukan di dalam UUD 1945. Pendiri negara Indonesia menentukan pilihan yang khas dan inovatif tentang bentuk negara dalam hubungannya dengan agama. Suatu pilihan bahwa negara Indonesia adalah negara yang berdasarkan atas 'Ketuhanan Yang Maha Esa (Pasal 29 ayat (1) UUD 1945). Ketentuan ini mengikat negara sebagai organisasi. Ketentuan tersebut menguatkan sila pertama dari dasar negara Pancasila. Ayat ini ingin menjelaskan bahwa negara Indonesia bukanlah negara sekuler dan bukan negara agama. Oleh karena itu, setiap lembaga atau institusi negara harus mendasarkan produk-produknya pada Ketuhanan Yang Maha Esa Ini.

Dasar Ketuhanan Yang Maha Esa tercantum dalam sila pertama Pancasila dan Pasal 29 ayat (2) UUD 1945 merupakan suatu staatsfundamentalnorm. Dalam pengertian ini Ketuhanan Yang Maha Esa merupakan prinsip konstitutif maupun regulatif bagi tertib hukum Indonesia, sehingga merupakan suatu pangkal tolak derivasi bagi tertib hukum
Indonesia serta hukum positif yang berada di bawahnya.

Pancasila yang di dalamnya terkandung nilai-nilai religius, nilai hukum moral, nilai hukum kodrat, dan nilai hukum Tuhan merupakan suatu sumber hukum material bagi hukum positif Indonesia. Dengan demikian Pancasila menentukan isi dan bentuk peraturan perundang-undangan di Indonesia yang tersusun secara hierarkhis. Dalam susunan yang hierarkhis ini Pancasila menjamin keserasian atau tiadanya kontradiksi di antara berbagai peraturan perundang-undangan secara vertikal maupun horisontal.

Bangsa Indonesia sebagai salah satu bangsa di dunia memiliki karakteristik, baik dalam konteks geopolitiknya maupun struktur sosial budayanya, yang berbeda dengan bangsa lain di dunia ini. Oleh karena itu para founding fathers Republik ini memilih dan merumuskan suatu dasar filosofi, suatu kalimatun sawa yang secara objektif sesuai dengan realitas bangsa ini, yaitu suatu dasar filsafat bangsa dan Negara Indonesia yang sila pertamanya berbunyi "Ketuhanan Yang Maha Esa", di tengah-tengah negara ateis, sekuler serta negara teokrasi. Perumusan dasar filosofi negara ini dalam suatu proses yang cukup panjang dalam sejarah. Negara Indonesia dengan dasar filosofi 'Ketuhanan Yang Maha Esa' memiliki ciri khas jika dibandingkan dengan tipe negara ateis dan negara sekuler. Oleh karena itu dalam negara yang berdasar atas Ketuhanan Yang Maha Esa, kehidupan agama tidak dipisahkan sama sekali melainkan justru agama mendapatkan legitimasi filosofis, yuridis dan politis dalam negara, sebagaimana terkandung dalam Pembukaan UUD 1945. Secara filosofis Ketuhanan Yang Maha Esa terkandung dalam sila pertama.

Konstitusi menempati posisi yang sangat penting dalam perkembangan kehidupan berbangsa dan bernegara. Konstitusi merupakan aturan dasar ketatanegaraan yang dibuat oleh masyarakat guna memberikan arah penyelenggaraan hubungan kehidupan berbangsa dan bernegara, tidak terkecuali persoalan Hak Asasi Manusia (HAM). Konstitusi tidak saja memberikan gambaran dan penjelasan tentang mekanisme hubungana antara lembaga-lembaga negara, lebih dari itu di dalamnya ditemukan letak relasional dan kedudukan dan kewajiban warga negara (Majda El-Muhtaj, 2007 : 8). 
Pasal 27 Ayat (1) (2), Pasal 28, Pasal 29 Ayat (2), Pasal 30 Ayat (1), Pasal 31 Ayat (1) dan Pasal 34 Undang-Undang Dasar 1945 (konstitusi tertulis) sebelum perubahan dapat dikatakan tidak mencantumkan secara tegas jaminan hak asasi manusia. UUD 1945 hanya berisi tujuh butir ketentuan yang juga tidak sepenuhnya dapat disebut sebagai jaminan hak asasi manusia. Namun setelah perubahan kedua UUD 1945 tahun 2000, ketentuan mengenai hak asasi manusia dan hak asasi warga negara dalam Pasal 27 Ayat (1) (2), Pasal 28, 28 A, Pasal 28 B Ayat (1) (2), Pasal 28 C Ayat (1) (2), Pasal 28D Ayat (1) (2) (3) (4), Pasal 28 E (1) (2) (3), Pasal 28F, Pasal $28 \mathrm{G}(1)$ (2), Pasal $28 \mathrm{H}$ (1) (2) (3) (4), Pasal 28 I (1) (2) (3) (4) (5), Pasal 29 Ayat (2) UUD 1945 telah mengalami banyak perubahan yang sangat mendasar, jika diperhatikan dengan sungguh-sunguh hanya ada 1 ketentuan saja yang memang benarbenar memberikan jaminan konstitusional, yaitu Pasal 29 ayat (2).

Ketentuan Pasal 29 ayat (2) UUD 1945 memberikan dasar tanggungjawab negara dalam memberikan jaminan dan perlindungan kepada setiap penduduk untuk memeluk dan menjalankan agama dan kepercayaanya. Untuk mengetahui inti dan makna tentang kebebasan atau kemerdekaan beragama maka perlu dikaji pikiran-pikiran yang diutarakan pada waktu UUD 1945 yang disusun oleh BPUPKI dan PPKI, serta pikiranpikiran pada saat Amandemen UUD 1945.

Sebagai perbandingan, rumusan mengenai kebebasan beragama dapat dilihat dalam dua konstitusi yang pernah berlaku di Indonesia yakni Konstitusi RIS dan Undang-Undang Dasar Sementara 1950 (UUDS 1950). Konstitusi RIS lahir setelah disahkannya pernyataan dunia tentang Hak-hak Asasi Manusia oleh PBB tanggal 10 Desember 1948. Konstitusi RIS 1949 terdiri dari 157 Pasal. Hak Asasi Manusia dicantumkan secara khusus dalam bab v, dari Pasal 7 sampai Pasal 33, yang memberikan jaminan dan perlindungan terhadap hak-hak asasi itu tercantum hak-hak hukum, politik, ekonomi, agama, peradilan bebas, praduga tak bersalah dan lain-lain.

Rumusan mengenai kebebasan beragama, tercantum dalam Pasal 18 Konstitusi RIS 1949, yang menyatakan, bahwa :

" Setiap orang berhak atas kebebasan pikiran keinsyafan batin dan agama, hak ini meliputi pula kebebasan bertukar agama atau keyakinan. Begitu pula kebebasan menganut agamanya atau kejakinannya. Begitu pula kebebasan menganut agamanja atau keyakinannja. Baik sendiri maupun bersamasama dengan orang lain, baik dimuka umum maupun dalam lingkungannya sendiri dengan dijalan mengajarkan, mengamalkan, beribadat, mentaati perintah dan aturanaturan agama, serta dengan jalan mendidik anak-anak dalam dan kejakinan orang tua mereka."

Sementara Undang-Undang Dasar Sementara 1950, landasannya tidak berbeda dengan Konstitusi RIS 1949, yaitu sangat dipengaruhi oleh Deklarasi Universal Hak-hak Asasi Manusia PBB. UUDS 1950 mengatur hak asasi warga negaranya dalam bab $\mathbf{v}$ tentang hak-hak dan kebebasan-kebebasan dasar manusia. Pasal yang mengenai hak-hak asasi manusia terdiri dari 28 Pasal, yaitu Pasal 7 sampai Pasal 34. UUDS 1950 menjamin lebih konkrit kebebasan berpolitik, menyatakan pikiran secara terbuka, keleluasaan dalam peradilan, kebebasan ekonomi dan hak-hak dasar lainnya. Khusus mengenai kebebasan beragama diatur di dalam Pasal 18 UUDS 1950, yang menjamin: kebebasan keinsyafan batin (gewetensvrijheid), kebebasan berpikir (denverjheid), dan kebebasan beragama (godsdienstvrijheid).

Pasal 43 UUDS 1950 merumuskan kebebasan beragama sebagai berikut.

1. Negara berdasarkan atas ke-Tuhanan Yang Maha Esa.

2. Negara menjamin kemerdekaan tiap-tiap penduduk untuk memeluk agamanya masing-masing dan untuk beribadat menurut agama dan kepercayaan itu.

3. Penguasa memberi perlindungan yang sama kepada segala perkumpulan dan persekutuan agama yang diakui. Pemberian sokongan berupa apapun oleh penguasa kepada pejabat-pejabat agama dan persekutuan-persekutuan atau perkumpulan-perkumpulan dilakukan atas dasar sama hak.

4. penguasa mengawasi supaya segala persekutuan dan perkumpulan agama patut dan taat kepada undang-undang, termasuk aturan-aturan hukum yang tak tertulis (Muh Yamin, 1960 : 182-183).

Ruh dan semangat Pasal 29 UUD 1945 sebagai dasar kebebasan beragama di atas terus mengalami pemaknaan dalam 
perjalanan sejarah. Hal ini dapat dilihat berbagai pemikiran muncul setelah kembali kepada UUD 1945 dengan Dekrit 5 Juli 1959, kemudian dikukuhkan ke dalam Keputusan Presiden RI No. 150 Tahun 1959. Diantara subtansi dari konsideran keputusan Presiden tersebut sebagai berikut :

a) Bahwa anjuran Presiden dan Pemerintah untuk kembali kepada UUD 1945, yang disampaikan kepada segenap rakyat Indonesia pada tanggal 22 April 1959, tidak memperoleh keputusan dari konstituante sebagaimana ditentukan dalam Undang-Undang Dasar Sementara;

b) Bahwa sehubungan dengan pernyataan sebagian terbesar anggota-anggota sidang pembuat Undang-Undang Dasar untuk tidak menghadiri lagi sidang, konstituante tidak mungkin lagi menyelesaikan tugas yang dipercayakan oleh rakyat kepadanya;

c) Bahwa hal yang demikian menimbulkan keadaan ketatanegaraan yang membahayakan persatuan dan keselamatan negara, nusa dan bangsa, serta merintangi pembangunan semesta untuk mencapai masyarakat adil dan makmur;

d) Bahwa dengan dukungan dari bagian terbesar rakyat Indonesia dan didorong oleh keyakinan kami sendiri, kami terpaksa menempuh satu-satunya jalan untuk menyelamatkan Negara Proklamasi;

e) Bahwa kami berkeyakinan bahwa Piagam Jakarta tertanggal 22 Juni 1945 menjiwai Undang-Undang Dasar 1945 dan adalah merupakan suatu rangkaian kesatuan dengan konstitusi tersebut (Jazim Hamidi dkk, 2001 : 97).

Keppres No. 150 Tahun 1959 di atas menetapkan pembubaran konstituante, menetapkan UUD 1945 berlaku lagi bagi segenap bangsa Indonesia dan seluruh tumpah darah Indonesia, terhitung mulai tanggal penetapan dekrit ini dan tidak berlakunya lagi Undang-Undang Dasar Sementara, menetapkan Majelis Perwakilan Rakyat Sementara, yang terdiri atas anggota-anggota Dewan Perwakilan Rakyat, ditambah dengan utusan-utusan dari daerahdaerah dan golongan serta pembentukan Dewan Pertimbangan Agung Sementara, akan diselenggarakan dalam waktu yang sesingkat-singkatnya. Naskah UUD 1945 juga dilampirkan dalam Keputusan Presiden tersebut diundangkan dalam Lembaran Negara Republik Indonesia Nomor 75 Tahun 1945 dengan berita Republik Indoneisa Nomor 7 tahun II tanggal 15 Pebruari 1946 (Sri Soemantri, 1992 : 52-71). khusus bab tentang agama tidak ada perbedaan. Perbedaan hanya terdapat pada ayat (1) yang berbunyi : "Negara berdasar atas keTuhanan Yang Maha Esa”. (BRI No. 7 tahun 1946) sedangkan menurut LN No. 75 Tahun 1959 berbunyi " Negara berdasarkan atas ke-Tuhanan Yang Maha Esa"(adanya akhiran kan).

Pada tahunn 1965, terjadi pemberontakan Gerakan 30 September yang dilakukan oleh Partai Komunis Indonesia (G30S/PKI) yang kemudian mengakibatkan terjadinya koreksi total terhadap penyelenggaran pemerintahan. Rakyat Indonesia melalui wakil-wakilnya di MPRS, menuntut agar Pancasila dan UUD 1945 dilaksanakan secara murni dan konsekuen. Hal dapat di artikan bahwa jaminan terhadap hak Asasi Manusia yang telah diatur dalam UUD 1945 harus menjadi dasar penyelenggaraan pemerintahan. Hal ini di latarbelakangi oleh praktek pelaksanaan UUD 1945 yang masa lalu mengabaikan Hak Asasi Manusia yang mungkin juga diakibatkan karena sedikitnya pasal-pasal tentang Hak Asasi Manusia. Berdasarkan hal tersebut MPRS memerintahkan agar disusun piagam tantang Hak-Hak Asasi Manusia yang lengkap.

MPRS melalui Panitia Ad Hoc IV menghasilkan suatu rancangan Piagam hak-Hak Asasi Manusia, namun rancangan tersebut tidak berhasil menjadi suatu Ketetapan MPR. Walaupun baru sampai pada tingkatan Rancangan (tidak disetujui), tetapi sudah dapat diketahui persepsi terhadap hak asasi pada waktu itu. Perkembangan selanjutnya, dikeluarkan TAP MPRS No.XXvII/ MPRS/1966 tentang Agama, Pendidikan dan Kebudayaan. Pasal 1 berbunyi : "Menetapkan pendidikan agama menjadi mata pelajaran di sekolah-sekolah mulai dari sekolah dasar sampai dengan universitas-universitas negeri"

Lebih lanjut, pada penjelasan huruf (a) TAP MPRS tersebut dinyatakan bahwa semua agama yang diakui pemerintah diberikan kesempatan yang sama. Berdasarkan Tap MPRS No.XXvII/MPRS/1966 tersebut jelas tersirat pemikiran, bahwa pemerintah menjadi 
sumber legitimasi agama-agama, sehingga berwenang melakukan interpretasi terhadap ajaran agama atau kepercayaan tertentu.

Pemikiran tentang kebebasan beragama, kemudian dapat dilihat pada TAP MPR No.Il/ MPR/1988 tentang GBHN, pada bagian Agama dan Kepercayaan terhadap Tuhan Yang Maha Esa, Sosial Budaya, butir I (b) dinyatakan bahwa "Kepercayaan terhadap Tuhan Yang Maha Esa tidak merupakan agama. Pembinaan terhadap Kepercayaan terhadap Tuhan Yang Maha Esa dilakukan agar tidak mengarah pada pembentukan agama baru, untuk mengefektifkan pengambilan langkah yang perlu agar pelaksanaan kepercayaan terhadap Tuhan Yang Maha Esa benar-benar sesuai dengan dasar Ketuhanan Yang Maha Esa menurut dasar kemanusiaan yang adil dan beradab"

Berdasarkan pernyataan di atas, pemerintah mengkhawatirkan kepercayaan terhadap Tuhan Yang Maha Esa akan menjadi agama baru, dengan demikian penganut aliran kepercayaan diharapkan memilih satu agama yang ada di Indonesia. Kecenderungan Pemerintah yaitu mengakui kemerdekaan aliran kepercayaan atau paling tidak kedudukannya dibedakan dari agama.

Pada era reformasi, disadari pentingnya perlindungan hak asasi manusia dan pelaksanaan hak asasi dalam menyelenggarakan kehidupan bermasyarakat, berbangsa dan bernegara. Bangsa Indonesia sebagai bagian masyarakat dunia patut menghormati hak asasi manusia yang tercantum dalam Deklarasi Universal Hak Asasi Manusia (DUHAM) PBB tahun 1948. Untuk itu perlunya ada Ketetapan MPR tentang Hak Asas Manusia. TAP MPR No.XvIl/MPR/1998, yang di dalam Pasal 5 memuat sistematika naskah Hak Asasi Manusia sebagai berikut :

1. Pandangan dan sikap bangsa Indonesia terhadap hak asasi manusia;

2. Piagam Hak Asasi Manusia.

Ketetapan MPR tersebut sebagai tindak lanjut dari Permusyawaratan dalam Sidang Istimewa MPR RI tanggal 10 sampai dengan 13 Nopember 1998 yang membahas Rancangan TAP MPR tentang Hak Asasi Manusia yang dipersiapkan oleh Badan Pekerja MPR RI. Pada dasarnya pemikiran yang tertuang di dalam TAP ini terhadap Hak Asasi Manusia, bahwa penjabaran maupun pengaturannya harus sesuai dengan sistem nilai yang terkandung dalam Pancasila, maka pada tanggal 23 September 1999 diundangkannya Undang-Undang No.39 Tahun 1999 tentang Hak Asasi Manusia. Dalam Pasal 1 ayat (1) dijelaskan yang dimaksud dengan hak asasi manusia adalah seperangkat hak yang melekat pada hakikat manusia sebagai mahluk Tuhan Yang Maha Esa dan merupakan anugrah-Nya yang wajib dihormati, dijunjung tinggi dan dilindungi oleh negara, hukum, pemerintah dan setiap orang demi kehormatan serta perlindungan harkat dan martabat manusia.

MPR memperdebatkan kembali mengenai dasar negara dan agama antara tahun 1990-2002. Hal yang membedakan adalah pada masa lalu esensi perdebatanya mengenai perlunya agama sebagai dasar negara, sedangkan perdebatan di MPR 19992002 tidak lagi mengenai agama sebagai dasar negara melainkan perdebatan tentang hubungan agama dan negara. Fraksi-fraksi di PAH I pada masa sidang tahun 2000 sudah mulai mengajukan pandangannya mengenai perubahan UUD 1945 berkaitan dengan Pasal 29 UUD 1945.

\section{Ruang Lingkup Hak Atas Kebebasan Beragama dan Berkepercayaan}

Kebebasan beragama yang sangat luas dan dilandasi konsep yang subyektif, serta dipengaruhi oleh berbagai faktor, seperti geografis, budaya, dan sosial-ekonomi, maka sulit untuk menentukan tentang apa saja yang termasuk ke dalam hak atas kebebasan beragama. Untuk mengatasi ketidakjelasan konsep tersebut, maka penulis mengutip kebebasan sebagaimana diatur di dalam Deklarasi Penghapusan Intoleransi dan Diskriminasi Agama. Dimana materi muatannya terdiri dari seperangkat unsurunsur yang harus dijamin oleh negara dalam keadaaan apapun, tanpa mempertimbangkan ketersediaan sumberdaya. Adapun materi yang diatur dalam Deklarasi Penghapusan Intoleransi dan Diskriminasi Agama, adalah sebagai berikut :

a. To worship or assemble in connection with a religion or belief, and to

establish and maintain places for these purposes; (bersembahyang atau berkumpul dalam kaitannya dengan keagamaan atau keyakinan, dan mendirikan dan memelihara tempat untuk maksud ini) 
b. To establish and maintain appropriate charitable or humanitarian institutions; (mendirikan dan memelihara lembaga derma atau kemanusiaan yang sesuai)

c. To make, acquire and use to an adequate extent the necessary articles and materials related to the rites or customs of a religion or belief; (membuat, memperoleh dan menggunakan sampai pada tingkat tertentu pasal-pasal dan bahan-bahan yang terkait dengan ritual atau kebiasaan suatu agama atau keyakinan)

d. To write, issue and disseminate relevant publications in these areas; (menulis, menerbitkan dan menyebarluaskan publikasi yang relevan dalam wilayah ini)

e. To teach a religion or belief in places suitable for these purposes; (menyampaikan pengajaran agama atau keyakinan di tempat yang cocok untuk maksud ini)

f. To solicit and receive voluntary financial and other contributions from individuals and institutions; (mencari dan menerima sumbangan keuangan sukarela dan pemberian lain dari perseorangan dan dari kelembagaan)

g. To train, appoint, elect or designate by succession appropriate leaders called for by the requirements and standards of any religion or belief; (melatih, menunjuk, memilih atau menugaskan melalui suksesi pemimpin yang tepat dan memenuhi syarat dan standar suatu agama atau keyakinan)

h. To observe days of rest and to celebrate holidays and ceremonies in accordance with the precept of one's religion or belief; (merayakan hari istirahat, hari raya dan kegiatan keagamaan sesuai ajaran suatu agama atau keyakinan)

i. To establish and maintain communications with individuals and communities in matters of religion and belief at the national and international levels. (menetapkan dan memelihara komunikasi dengan individu dan komunitas terkait dengan soal-soal kegamaan pada tingkat nasional dan internasional (Pasal 6 Deklarasi Penghapusan Semua Bentuk Intolenransi dan Diskriminasi Berdasarkan Agama atau Kepercayaan (Diumumkan oleh resolusi Sidang Perserikatan Bangsa- Bangsa No. 36/55 pada tanggal 25 Nopember 1981).
Berdasarkan materi yang diatur dalam Deklarasi Penghapusan Intoleransi dan Diskriminasi Agama, dapat dilihat bahwa ruang lingkup kebebasan beragama demikian luas, Konsekuensi makna dari hak atas kebebasan beragama dan berkepercayaan menjadi luas pula, terutama untuk menempatkan hak atas kebebasan beragama itu dalam posisi di atas hak-hak asasi manusia lainnya, baik hak-hak sipil dan politik, maupun hak-hak di bidang ekonomi, sosial dan budaya. Artinya, hak atas kebebasan beragama terkait dengan hak-hak asasi lainnya yang diatur dalam berbagai Piagam Hak Asasi Manusia, seperti:

1. hak atas perlindungan hukum yang sama tanpa diskriminasi

2. hak atas bantuan yang efektif dari pengadilan nasional

3. hak asasi manusia atas perlindungan hukum terhadap gangguan atau pelanggaran terhadap urusan pribadinya, keluarganya;dan rumah tangganya

4. hak akses kebebasan bergerak dan berdiam di dalam batas-batas setiap negara;

5. hak atas untuk menikah dan membentuk keluarga dengan tidak dibatasi kebangsaan, kewarganegaraan atau agama;

6. hak atas kebebasan berpikir dan mengeluarkan pendapat

7. hak atas kebebasan berserikat dan berkumpul secara damai.

8. hak atas kebebasan dari prektek diskriminasi sosial (discriminatory social practices),

9. hak atas pendidikan (Pasal 7, 8, 12, 13, 14, 16, 19, 20 DUHAM)

3. Kebijakan Pemerintah dalam Pelaksanaan Kebebasan Beragama dan Berkepercayaan

Hak atas kebebasan beragama dan berkepercayaan menjadi tanggung jawab negara. Hak atas kebebasan beragama dengan tegas dijamin oleh Undang-Undang Dasar 1945 Pasal 28E dan Pasal 29. Selain dijamin di dalam konstitusi, juga dijamin di berbagai peraturan perundangan. Tahun 2005 telah diratifikasi konvensi internasional hakhak sipil dan politik melalui Undang-Undang Nomor 12 Tahun 2005. Artinya secara yuridis, jaminan terhadap kebebasan beragama dan berkeyakinan sangat kuat di dalam rezim hukum di Indonesia. Bahkan, kalau diperhatikan ketentuan di dalam konstitusi, 
hak atas kebebasan beragama ini diberikan dengan kualitas non derogable rights atau hak yang tidak boleh dicabut dalam situasi apapun. Jadi, kualitas dari hak kebebasan beragama dan berkepercayaan ini memiliki kedudukan atau status yang sangat tinggi di dalam heirarki hak asasi manusia. Oleh karena itu, Negara Republik Indonesia memiliki kewajiban konsitusional untuk menjamin terpenuhinya hak-hak ini.

Komponen hak-hak kebebasan beragama ada dua aspek kebebasan yang terkandung di dalam hak atas kebebasan beragama itu. Yang pertama adalah, aspek kebebasan internal atau disebut dengan forum internum, dan yang kedua adalah aspek kebebasan eksternal atau disebut forum eksternum. Apa yang dimaksud kebebasan internum? Itu adalah kebebasan individual yang dimiliki oleh setiap orang untuk meyakini, atau berpikir, atau memilih agama yang diyakininya, meyakini doktrindoktrin keagamaan yang menurut dia benar. Forum internum tidak bisa diintervensi oleh negara. Sedangkan forum eksternal atau kebebasan eksternal, yang dimaksud dengan itu adalah kebebasan seseorang untuk mengekspresikan atau memanifestasikan agama yang diyakininya itu melalui dakwah, melalui pendidikan, dan melalui saranasarana yang lain. Kebebasan ini juga harus dijamin untuk setiap orang pemeluk agama bebas menyampaikan misi agamanya, mendakwahkannya, mewariskannya kepada anak-cucunya, dan sebagainya. Itu harus dijamin oleh setiap negara. Kebebasan juga dikenakan pembatasan. Walaupun kualitas dari hak ini berstatus sangat tinggi karena bersifat non derogable, tetapi terhadap kebebasan ini juga diterapkan pembatasanpembatasan. Tetapi, pembatasannya ditujukan terutama kepada kebebasan yang bersifat eksternal, yaitu dalam konteks menyebarluaskan ajaran agama itu, mewariskannya, mendakwahkannya, dan seterusnya seperti itu.

Pembatasan yang diperkenankan untuk kebebasan adalah (1) pembatasan dari sudut keamanan masyarakat, (2) ketertiban masyarakat atau public order, kesehatan atau moralitas masyarakat, (3) hak dan kebebasan orang lain. Inilah alat ukur untuk membatasi kebebasan beragama itu, khususnya kebebasan dalam lingkup kebebasan eksternal, tetapi pembatasanpembatasan harus dinyatakan oleh hukum, bukan didasarkan oleh kesepakatan atau apa pun, tetapi harus dinyatakan melalui hukum.

Dalam tingkat praktik kenegaraan, negara membentuk satu kementerian khusus yang membidangi urusan agama yaitu Kementerian Agama. Hari-hari besar keagamaan dihormati dalam praktik bernegara. Demikian pula hukum agama dalam hal ini syari'at Islam yang terkait dengan nikah, talak, rujuk, waris, hibah, wasiat, wakaf, ekonomi syari'ah, dan lain-lain telah menjadi hukum negara khususnya yang berlaku bagi pemeluk agama Islam; dasar falsafah negara, konstitusi negara, serta praktik dan kenyataan ketatanegaraan.

Penghormatan Negara Indonesia atas berbagai konvensi serta perangkat hukum internasional termasuk hak asasi manusia haruslah tetap berdasarkan pada falsafah dan konstitusi Negara Kesatuan Republik Indonesia. Dalam kerangka itulah dimaknai prinsip negara hukum Indonesia yang tidak harus sama dengan prinsip negara hukum dalam arti rechtsstaat maupun the rule of law. Prinsip negara hukum Indonesia harus dilihat dengan cara pandang UUD 1945, yaitu negara hukum yang menempatkan prinsip KetuhananYang Maha Esa sebagai prinsip utama, serta nilai-nilai agama yang melandasi gerak kehidupan bangsa dan negara, bukan negara yang memisahkan hubungan antara agama dan negara (separation of state and religion), serta tidak semata-mata berpegang pada prinsip individualisme maupun prinsip komunalisme.

Konstitusi Negara Kesatuan Republik Indonesia tidak memberikan kemungkinan adanya kampanye kebebasan untuk tidak beragama, kebebasan untuk promosi anti agama serta tidak memungkinkan untuk menghina atau mengotori ajaran agama atau kitab-kitab yang menjadi sumber kepercayaan agama ataupun mengotori nama Tuhan. Elemen inilah yang merupakan salah satu elemen yang menandakan perbedaan pokok antara negara hukum Indonesia dengan negara hukum Barat, sehingga dalam pelaksanaan pemerintahan negara, pembentukan hukum, pelaksanaan pemerintahan serta peradilan, dasar ketuhanan dan ajaran serta nilai-nilai agama menjadi alat ukur untuk menentukan hukum yang baik atau hukum yang buruk, bahkan untuk menentukan hukum yang konstitusional atau hukum yang tidak konstitusional. Dalam kerangka pemikiran seperti diuraikan di atas, pembatasan hak asasi manusia atas dasar 
pertimbangan "nilai-nilai agama" sebagaimana disebutkan dalam Pasal 28J ayat (2) UUD 1945 merupakan salah satu pertimbangan untuk membatasi pelaksanaan hak asasi manusia. Hal tersebut berbeda dengan Article 18 ICCPR yang tidak mencantumkan nilainilai agama sebagai pembatasan kebebasan individu; Jaminan atas kebebasan beragama ini telah banyak dikonstruksi baik melalui instrumen hukum nasional maupun instrumen hukum internasional.

Sebagai realisasi dari kebijakan tersebut adalah terbitnya peraturan perundanganundangan antara lain:

1. Undang-Undang Nomor 1/PNPS/ 1965 tentang Pencegahan Penyalahgunaan dan/atau Penodaan Agama;

2. Keputusan bersama Menteri Agama dan Menteri Dalam Negeri No. 01/Ber/MDNMAG/1969 Tentang Pelaksanaan Tugas Aparatur Pemerintahan Dalam Menjamin Ketertiban dan Kelancaran Pelaksanaan Pengembangan dan Ibadat Agama oleh Pemeluk-Pemelunya dengan telah diganti dengan Peraturan Bersama Menteri Agama dan Menteri Dalam Negeri Nomor: 9 Tahun 2006, Nomor: 8 Tahun 2006 Tentang Pedoman Pelaksanaan Tugas Kepala Daerah/Wakil Kepala Daerah Dalam Pemeliharaan Kerukunan Umat Beragama, Pemberdayaan Forum Kerukunan Umat Beragama, dan Pendirian Rumah Ibadah;

3. Instruksi Menteri Agama Nomor : 4 Tahun 1978 tanggal 14 April 1978 tentang Kebijaksanaan Mengenai Aliran Kepercayaan;

4. Keputusan Menteri Agama No. 70 Tahun 1978 tanggal 1 Agustus 1978 tentang Pedoman Penyiaran Agama;

5. Keputusan Menteri Agama No. 77 Tahun 1978 tanggal 15 Agustus 1978 tentang Bantuan Asing bagi Lembaga Keagamaan di Indonesia;

6. Keputusan Menteri Agama Nomor 44 Tahun 1978 tentang Pelaksanaan Dakwah Agama dan Kuliah Subuh melalui Radio;

7. Kepusan Bersama Menteri Dalam Negeri Nomor 1 Tahun 1979 tentang Tatacara Pelaksanaan Penyiaran Agama dan Bantuan Luar Negeri Kepada Lembaga Keagamaan di Indonesia;

8. Instruksi Menteri Agama Nomor; 8 tahun 1979 tanggal 27 September 1979 tentang Pembinaan, Bimbingan dan Pengawasan terhadap Organisasi dan Aliran dalam Islam yang bertentangan dengan Ajaran Islam;

9. Keputusan Menteri Agama Nomor 35 Tahun 1980 tanggal 30 juni 1980 tentang Wadah Musyawarah Antar Umat Beragama;

10. Surat Edaran Menteri Agama No; MA/432/1981 perihal Penyelenggaraan Peringatan Hari-Hari Besar Keagamaan;

11. Instruksi Menteri Agama RI Nomor: 3 Tahun 1995 Tentang Tindak Lanjut Keputusan Bersama Menteri Agama dan Menteri dalam Negeri Nomor: 01/BER/ MDN-MAG/1969 di Daerah.

Bersamaan dengan diberikannya hak atas kebebasan beragama, negara juga berhak memberikan pengaturan dan batasan atas pelaksanaan kebebasan beragama. Pembatasan itu secara eksplisit terkandung dalam Pasal 28J ayat (2) UUD 1945 yang menyatakan, bahwa :

"Dalam menjalankan hak dan kebebasannya, setiap orang wajib tunduk kepada pembatasan yang ditetapkan dengan undang-undang dengan maksud sematamata untuk menjamin pengakuan serta penghormatan atas hak dan kebebasan orang lain dan untuk memenuhi tuntutan yang adil sesuai dengan pertimbangan moral, nilai-nilai agama, keamanan, dan ketertiban umum dalam suatu masyarakat demokratis."

Selain melindungi hak asasi manusia sebagai hak yang secara kodrati melekat dan bersifat universal, negara juga memberikan kewajiban dasar yang merupakan seperangkat kewajiban yang apabila tidak dilaksanakan, tidak memungkinkan terlaksana dan tegaknya hak asasi manusia (Pasal 1 angka 2 UndangUndang Nomor 39 Tahun 1999). Secara integral, UUD 1945 mengatur bahwa dalam menegakkan hak asasi, setiap elemen baik negara, pemerintah, maupun masyarakat juga memiliki kewajiban dasar yang mendukung penghormatan HAM itu sendiri. Pembatasan lainnya juga diberikan dalam Pasal 19 ayat (3) International covenan on civil and political rights (ICCPR) yang menyatakan bahwa hak yang diberikan atas kekebasan beragama juga harus dilaksanakan dengan penuh rasa tanggung jawab.

Pembatasan ini dapat diberikan hanya dengan pengaturan menurut Undang-Undang yang ditujukan untuk (a) menghormati hak dan 
reputasi orang lain, (b) melindungi keamanan nasional, ketertiban umum, kesehatan masyarakat dan/atau moral. Selengkapnya Pasal 19 ayat (3) ICCPR menyatakan: "The exercise of the rights provided for in paragraph2 of this article carries with it special duties and responsibilities. It may therefore be subject to certain restrictions, but these shall only be such as are provided by law and are necessary:(a) For respect of the rights or reputations of others; (b) For the protection of national security or of public order (order public), or of public health or morals."

Kebebasan beragama yang diberikan kepada setiap manusia bukanlah merupakan kebebasan yang bebas nilai dan kebebasan an sich, melainkan kebebasan yang disertai dengan tanggung jawab sosial untuk mewujudkan HAM bagi setiap orang. Dalam hal ini negara memiliki peran sebagai penyeimbang antara hak asasi dan kewajiban dasar untuk mewujudkan HAM yang berkeadilan. Negara memiliki peran untuk memastikan, bahwa dalam pelaksanaan kebebasan beragama seseorang tidak melukai kebebasan beragama orang lain. Di sinilah negara akan mewujudkan tujuannya yakni untuk mencapai kehidupan yang lebih baik (the best life possible).

Pasal 1 ayat (3) UUD 1945, Indonesia telah mendeklarasikan diri sebagai negara hukum. Konsep negara hukum ini dikenal juga dengan istilah "rechtsstaat" dan "the rule of law". Konsep ini sekaligus menandakan bahwa penentu dalam penyelenggaraan kekuasaan negara adalah hukum (supremacy of law) dan bukan kekuasaan individu maupun kelompok semata-mata. Oleh karenanya, pelaksanaan maupun pembatasan HAM harus secara tegas dijalankan menurut hukum.

Kebebasan merupakan bentuk dari tanggung jawab sosial. Dimana kebebasan ajaran agama atau keyakinan dalam kehidupan publik termasuk dalam hak bertindak (freedom of act) yang dapat dibatasi dan diatur sehingga tidak menjadi ancaman bagi keteraturan social. Bahwa ketiadaan pengaturan dalam freedom of act dapat menimbulkan: 1) potensi konfilk masal; 2) anarkisme atas nama agama; 3) hegemoni kekuasaan dan mayoritas. Jadi undangundang dibuat untuk mencegah hal tersebut.

Hak kebebasan beragama tentulah bukan hak mutlak tanpa batas, melainkan dibatasi oleh kewajiban dan tanggung jawab seseorang untuk menghargai dan menghormati sesama manusia, apapun agamanya. Kovenan Internasional Tentang Hak-Hak Sipil dan Politik yang telah diratifikasi pemerintah memberikan kewenangan kepada pemerintah untuk melakukan pembatasanpembatasan dalam kehidupan keagamaan. Akan tetapi, harus diingat bahwa semua bentuk pembatasan atau pengaturan itu hanya boleh dilakukan dengan undang-undang.

Pembatasan kebebasan beragama hanya diperlukan jika mengarah kepada pembatasan untuk mewujudkan, mengimplementasikan, atau memanifestasikan ajaran agama atau keyakinan seseorang yang termasuk kebebasan bertindak (freedom to act). Jadi, pembatasan tidak mencakup hak kebebasan beragama dan berkeyakinan dalam pengertian freedom to be. Sebab, segaimana dijelaskan sebelumnya bahwa kebebasan untuk mengimplementasikan ajaran agama atau keyakinan bersifat derogable, boleh dibatasi, diatur, atau ditangguhkan pelaksanaannya. Dengan demikian tujuan utama pembatasan itu adalah untuk menangkal ancaman terhadap keselamatan orang (kehidupan, integritas, kesehatan mereka) atau kepemilikan mereka. Pembatasan itu semata-mata dimaksudkan untuk melindungi keselamatan seluruh masyarakat.

Regulasi atau pengaturan oleh negara dalam kehidupan beragama tetap diperlukan. Regulasi dimaksud dilakukan dalam rangka memberikan perlindungan kepada warga negara, bukan intervensi. Untuk tujuantujuan tersebut, negara perlu menetapkan rambu-rambu agar para pemeluk agama tidak mengajarkan hal-hal yang mengganggu ketertiban masyarakat dan kesehatan mereka, tidak mengajarkan kekerasan (violence) kepada siapa pun dan dengan alasan apa pun, dan tidak melakukan penghinaan terhadap pengikut agama lain.

Pembatasan dimaksud sebagaimana terbaca dalam Pasal 18, ayat (3): mencakup lima elemen berikut: keselamatan masyarakat (public savety), ketertiban masyarakat (public order), kesehatan masyarakat (public health), etik dan moral masyarakat (morals public), dan melindungi hak dan kebebasan mendasar orang lain (the fundemental rights and freedom of others). Secara lebih rinci diuraikan di bawah ini.

1. restriction for The protection of public Safety (Pembatasan untuk Melindungi Keselamatan Masyarakat). Dibenarkan 
pembatasan dan larangan terhadap ajaran agama yang membahayakan keselamatan pemeluknya. Contohnya, ajaran agama yang ekstrim, misalnya menyuruh untuk bunuh diri, baik secara individu maupun secara massal. Atau ajaran agama yang melarang penganutnya memakai helm pelindung kepala dalam berkendaraan.

2. restriction for The protection of public Order (Pembatasan untuk Melindungi Ketertiban Masyarakat). Pembatasan kebebasan memanifestasikan agama dengan maksud menjaga ketertiban umum atau masyarakat. Di antaranya, aturan tentang keharusan mendaftar ke badan hukum bagi organisasi keagamaan masyarakat; keharusan mendapatkan ijin untuk melakukan rapat umum; keharusan mendirikan tempat ibadat hanya pada lokasi yang diperuntukkan untuk umum; dan aturan pembatasan kebebasan menjalankan agama bagi nara pidana.

3. restriction for The protection of public Health (Pembatasan untuk Melindungi Kesehatan Masyarakat). Pembatasan yang diijinkan berkaitan dengan kesehatan publik dimaksudkan untuk memberi kesempatan kepada pemerintah melakukan intervensi guna mencegah epidemi atau penyakit lainnya. Pemerintah diwajibkan melakukan vaksinasi, Pemerintah dapat mewajibkan petani yang bekerja secara harian untuk menjadi anggota askes guna mencegah penularan penyakit berbahaya, seperti TBC.

4. restriction for The protection of Morals (Pembatasan untuk Melindungi Moral Masyarakat). Misalnya, melarang implementasi ajaran agama yang menyuruh penganutnya bertelanjang bulat ketika melakukan ritual.

5. restriction for The protection of The Fundamental rigths and Freedom of Others (Pembatasan untuk melindungi kebebasan dasar dan kebebasan orang lain).

6. proselytism (Penyebaran Agama): Dengan adanya hukuman terhadap tindakan proselytism, pemerintah dapat mencampuri kebebasan seseorang di dalam memanifestasikan agama mereka melalui aktivitas-aktivitas misionaris di dalam rangka melindungi agar kebebasan beragama orang lain tidak terganggu atau dikonversikan.

7. Pemerintah berkewajiban membatasi manifestasi dari agama atau kepercayaan yang membahayakan hak-hak fundamental dari orang lain, khususnya hak untuk hidup, hak kebebasan dari kekerasan, melarang perbudakan, kekejaman dan juga eksploitasi hak-hak kaum minoritas.

Dengan demikian, keberadaan peraturan perundang-undang dalam rangka menjamin kebebasan beragama dan berkepercayaan, secara filosofis memiliki latar belakang dan landasan yang kuat di dalam kehidupan bermasyarakat, berbangsa, dan bernegara. Pembentukan undang-undang di samping harus berdasarkan pada landasan filosofis, tentu perlu disesuaikan dengan kemajuan dan perkembangan serta tuntutan masyarakat. Selain itu, harus pula berdasarkan nilainilai agama, adat istiadat, dan budaya yang diyakininya. Hal ini merupakan landasan sosiologis dalam pembentukan hukum.

\section{Penutup}

1. Kemajemukan atau pluralisme dalam beragama dan berkepercayaan adalah suatu hal yang wajar karena hal tersebut adalah sunnatullah yang tidak dapat dihindari dan diingkari oleh umat manusia, oleh karena itu yang diharapkan adalah dari setiap warga masyarakat bisa menerima kemajemukan itu sebagaimana adanya dan negara dalam hal ini bertugas atau melaksanakan fungsi memberikan perlindungan serta jaminan pelaksanaan kebebasan beragama dan berkeyakinan tanpa membeda-bedakan umat mayoritas dan minoritas. Agama memainkan peran yang penting dalam kehidupan bernegara dan berbangsa terutama di Indonesia.

2. Agama adalah elemen absolut bagi pembangunan bangsa, ini berarti kepemilikan agama dan kepercayaan bagi bangsa Indonesia adalah merupakan "jati diri bangsa". Karena kemerdekaan yang diraih oleh bangsa Indonesia adalah peran besar dari agama dan kepercayaan di Indonesia. Dengan demikian penting politik hukum yang sedang dan akan dibuat oleh negara harus dapat memberikan jaminan perlindungan kebebasan beragama berkepercayaan atau berkeyakinan tanpa adanya diskriminasi bagi setiap warga negara Indonesia berdasarkan UUD 1945. 


\section{daftar Pustaka}

Ahmad Sukarja, 1995, piagam Madinah dan Undang-Undang dasar 1945, Kajian Perbandingan tentang Dasar Hidup Bersama Dalam Masyarakat Yang Majemuk, UI Press, Jakarta

Deliar Noer, 1990, Muhammad Hatta: Biografi Politik, LP3ES, Jakarta

Jajim Hamidi dan M. Husnu Abadi, 2001, Intervensi Negara terhadap Agama, UII Press, Yogyakarta M.Yamin, 1960, Naskah persiapan UUd 1945

Majda El-Muhtaj, 2007, Hak Asasi Manusia dalam Konstitusi Indonesia, Kencana Prenada Media Group, Jakarta

Sri Soemantri, 1987, prosedur dan Sistem perubahan Konstitusi, Alumni, Bandung 1992, Tinjauan Terhadap Tiga Undang-Undang dasar yang berlaku dan pernah berlaku di Indonesia, dalam Bunga Rampai Hukum Tata Negara Indonesia, Alumni, Bandung

Taufik Abdulah (Peng) 1998, Risalah Sidang BPUPKI dan PPKI, Sekretariat Negara, Widya Komputer Indonesia, Jakarta 